\title{
Penerapan Problem Based Learning (PBL) berbantuan Teknologi Informasi dan Komunikasi untuk Meningkatkan Kemampuan Berpikir Kritis Siswa Pada Konsep Pencemaran Lingkungan
}

\author{
Fitri Aryanti ${ }^{1}$, Hertien Surtikanti ${ }^{2}$, Riandi ${ }^{2}$ \\ ${ }^{1}$ Jurusan Pendidikan Biologi, FKIP, Universitas Pasundan \\ Jl. Tamansari No. 6-8, Bandung 40116 Indonesia \\ ${ }^{2}$ Jurusan Pendidikan Biologi, FPMIPA, Universitas Pendidikan Indonesia \\ Jl. Dr. Setiabudi No. 229, Bandung 40154 Indonesia \\ e-mail: fitri aryanti@unpas.ac.id
}

\begin{abstract}
Abstrak
Penelitian ini bertujuan untuk mengetahui peningkatan kemampuan berpikir kritis siswa pada konsep pencemaran lingkungan. Metode yang digunakan yaitu kuasi eksperimen dengan "the matching only pretest posttest control group design" yang dilaksanakan pada siswa kelas VII di salah satu SMP Negeri di Kota Bandung. Data kemampuan berpikir kritis dijaring melalui tes pilihan ganda beralasan. Kesimpulan penelitian ditarik berdasarkan hasil analisis pengolahan data menggunakan Uji Mann-Whitney U. Berdasarkan perhitungan N-gain menunjukkan terdapat peningkatan kemampuan berpikir kritis yaitu pada kelas kontrol adalah 0,17 dan kelas eksperimen adalah 0,37. Berdasarkan hasil analisis statistik menunjukkan bahwa penerapan Problem Based Learning berbantuan Teknologi Informasi dan Komunikasi (TIK) dapat meningkatkan kemampuan berpikir kritis.
\end{abstract}

Kata Kunci : Berpikir Kritis, PBL berbantuan TIK, Pencemaran Lingkungan

\begin{abstract}
This research aimed to determine the increasing of student critical thinking skills on the concept of environent pollution. The research method was quasi-experiment with the matching only pretest-posttest control group design were implemented at class VII in one of the junior high school in Bandung. The results were gathered by the multiple-choice test for critical thinking skills. Conclusions are drawn based on the result of the processing and data analysis using statistical nonparametric with Mann-Whitney U test. The gain-normalized results revealed that there was increasing of critical thinking skills. The increasing of critical thinking skills were 0.17 for the control class and 0.37 for the experiments class. Based on the result of the statistical analysis showed that the implementation Problem Based Learning with an Information Technology and Communication (ICT) assisted can increase of students critical thinking skills.
\end{abstract}

Keywords: Critical Thinking Skill, PBL with ICT-Assisted, Environment Pollution

\section{PENDAHULUAN}

Pembelajaran merupakan proses interaksi an-tara guru dengan siswa, siswa dengan siswa dan siswa dengan bahan ajar yang berlangsung da-lam situasi edukatif untuk mencapai tujuan ter-tentu. Interaksi atau hubungan timbal balik an-tara guru dan siswa ini merupakan syarat utama berlangsungnya proses pembelajaran. Tetapi pa-da kenyataannya seringkali guru terlalu aktif di dalam proses pembelajaran, sedangkan sebagian siswa hanya mendengarkan penjelasan guru, sehingga interaksi antara guru dengan siswa dalam proses pembelajaran tidak efektif (Syah, 2010). Menurut Kamdi dalam Mustaji (2010) proses pembelajaran di sekolah baru dilaksanakan untuk mencapai tujuan pembelajaran pada tingkat mengetahui, memahami, menggunakan dan belum sampai pada menumbuhkan kebiasaan berpikir tingkat tinggi yakni suatu yang paling esensi dari dimensi belajar. Seorang guru perlu merancang pembelajaran yang dapat mengembangkan kemampuan berpikir siswa.

Salah satu model pembelajaran interaktif yang bercirikan konstuktivis, student centered dan menekankan pada learning adalah model pembelajaran Problem Based Learning (PBL). PBL adalah model pembelajaran yang titik awal pembelajarannya berdasarkan pada masalah dalam kehidupan nyata. (Harsono, 2010). Ciri dari model ini yaitu penggunaan masalah kehidupan nyata sebagai sesuatu yang harus dipelajari siswa untuk melatih dan mengem- 
bangkan keterampilan berpikir dan keterampilan mengatasi masalah, mempelajari peranperan orang dewasa dan menjadi pelajar yang mandiri. Kolaborasi antar siswa dalam PBL dapat mendorong penyelidikan dan dialog bersama sehingga dapat mengembangkan keterampilan berpikir dan keterampilan sosial.

Rumusan masalah dari penelitian in yaitu bagaimanakah penerapan Problem Based Learning berbantuan Teknologi Informasi dan Komunikasi dapat mengembangkan kemampuan berpikir kritis siswa pada konsep pencemaran dan kerusakan lingkungan? Penelitian difokuskan pada masalah lingkungan dimana lokasi lingkungan sekolah yang diteliti sangat berdekatan dengan pasar sehingga sampah di lingkungan sekitarnya menjadi suatu topik permasalahan. Menurut UU Pengelolaan Sampah No. 18 Tahun 2008, sampah adalah sisa kegiatan sehari-hari manusia dan/atau proses alam yang berbentuk padat. Pertambahan penduduk dan perubahan pola konsumsi masyarakat dapat menimbulkan bertambahnya volume, jumlah dan karakteristik sampah yang semakin beragam. Sampah tidak dapat dihilangkan dari permukaan bumi, tapi setidaknya kita bisa mengurangi produksi sampah yang berlebihan. Adanya masalah tersebut diharapkan siswa dapat termotivasi dalam mengembangkan kemampuan berpikir kritisnya dengan menyelidiki masalah dan mencari informasi dari berbagai sumber sehingga siswa dapat menyumbangkan ide-idenya dalam menangani masalah tersebut.

Penelitian ini bertujuan untuk mengetahui peningkatan kemampuan berpikir kritis siswa. Hadiryanto (2009) mengungkapkan bahwa PBL dapat dijadikan salah satu alternatif model pembelajaran yang dapat meningkatkan kemampuan berpikir kritis siswa. Norris dan Ennis (Stiggins, 1994) memaparkan berpikir kritis sebagai keterampilan berpikir menggunakan proses mendasar untuk menganalisis argumen, memunculkan wawasan dan interpretasi ke dalam pola penalaran logis. Indikator kemampuan berpikir dibagi menjadi 5 kelompok yaitu memberikan penjelasan sederhana, membangun keterampilan dasar, membuat inferensi, membuat penjelasan lebih lanjut dan mengatur strategi dan taktik

Masalah-masalah yang disajikan dalam PBL diharapkan dapat mendorong siswa untuk menemukan bagaimana cara memecahkan suatu masalah. Dengan timbulnya pemikiran ter- sebut siswa akan terbiasa untuk bereksperimen dan mencari sumber informasi lebih banyak sehingga menemukan suatu solusi.

Penelitian dilakukan dengan memanfaatkan salah satu teknologi intenet berupa weblog atau blog. Penggunaan blog dapat dimanfaatkan sebagai media pembelajaran bagi siswa dan blog juga merupakan sebuah sarana untuk mengembangkan kemampuan siswa baik pengetahuan maupun keterampilan. Konten blog dapat berupa artikel (teks), audio, video dan gambar yang mendukung proses pembelajaran. Menurut Purwaningsih dan Pujianto (2009), peranan TIK dalam PBL dapat memberikan kemudahan dalam mencari sumber informasi. Akses informasi dapat terjadi tanpa terkendala tempat, jarak dan waktu. Selain itu juga dapat dijadikan sebagai media diskusi melalui blog, chatting maupun situs jejaring sosial yang memungkinkan setiap orang tergabung dalam suatu grup dalam bidang tertentu. Berdasarkan uraian diatas diharapkan dapat mengetahui peningkatan kemampuan berpikir kritis, memicu siswa untuk melakukan kajian-kajian dari berbagai sumber untuk mengurangi masalah tersebut. Selain itu dapat menjadi suatu tantangan bagi siswa sehingga mampu mengembangkan kemampuan berpikir kritis sekaligus memiliki sikap yang lebih positif dan bertanggung jawab untuk menyelesaikan permasalahan-permasalahan sampah tersebut.

\section{METODE PENELITIAN}

Metode yang digunakan yaitu quasi experimental dengan the matching only pretest posttest control group (Fraenkel, 2006). Desain ini menggunakan dua kelompok yaitu kelompok eksperimen dan kontrol, masing-masing kelompok diberikan pretest dan posttest. Kelompok eksperimen diberi perlakuan dengan penerapan PBL berbantuan TIK dan kelompok kontrol dengan pembelajaran konvensional metode ceramah.

Populasi dalam penelitian ini adalah siswa SMP kelas VII semester dua di kota Bandung. Sampel penelitian terdiri dari dua kelas masing-masing sebanyak 36 siswa yaitu siswa kelas VII-A sebagai kelas eksperimen dan siswa kelas VII-C sebagai kelas kontrol. Pengambilan sampel dilakukan secara purposive sampel dengan pertimbangan pada kelas eksperimen siswa mempunyai kemampuan mengoperasikan komputer dan mengakses internet. Instrumen yang digunakan yaitu soal kemampuan 
berpikir kritis yang terdiri dari 25 soal pilihan ganda beralasan yang dibuat berdasarkan 12 sub-indikator kemampuan berpikir kritis dan lembar kerja siswa (LKS). Data kuantitatif pada penelitian ini berupa skor tes awal dan tes akhir kemampuan berpikir kritis serta $\mathrm{N}$-Gain untuk mengetahui kategori peningkatan kemampuan berpikir kritis sebelum dan sesudah pembelajaran.

\section{HASIL DAN PEMBAHASAN}

Berdasarkan hasil analisis data kemampuan berpikir kritis siswa menunjukkan peningkatan skor pretest-posttest pada kelas kontrol dan kelas eksperimen.

Tabel 1. Rekapitulasi Uji Statistik Kemampuan Berpikir Kritis Siswa Kelas Eksperimen

\begin{tabular}{lccc}
\hline \multirow{2}{*}{ Komponen } & \multicolumn{3}{c}{ Eksperimen } \\
\cline { 2 - 4 } & Pretest & Postest & N-Gain \\
\hline Rata-rata & 17.08 & 47.22 & 0.37 \\
\hline Standar Deviasi & 6.78 & 16.54 & 0.19 \\
\hline Skor Maks & 36 & 84 & 0.79 \\
\hline Skor Min & 6 & 14 & 0.01 \\
\hline \multicolumn{5}{c}{ Uji Normalitas } \\
\hline Sig. $\alpha=0.05$ & 0.69 & 0.09 \\
\hline Keterangan & \multicolumn{4}{c}{ Berdistribusi Normal } \\
\hline \multicolumn{5}{c}{0.13} \\
\hline Sig. $\alpha=0.05$ & Uji Homogenitas \\
\hline Keterangan & 0.95 & 0.12 & 0.006 \\
\hline \multicolumn{4}{c}{ Homogen } \\
\hline Sig. $\alpha=0.05$ & Uji Mann-Whitney U \\
\hline Keterangan & 0.26 & 0.00 \\
\hline \multicolumn{5}{c}{ diterima } & $\mathrm{H}_{0}$ ditolak & $\mathrm{H}_{0}$ ditolak \\
\hline
\end{tabular}

Tabel 2. Rekapitulasi Uji Statistik Kemampuan Berpikir Kritis Siswa Kelas Kontrol

\begin{tabular}{lccc}
\hline \multirow{2}{*}{ Komponen } & \multicolumn{3}{c}{ Kontrol } \\
\cline { 2 - 4 } & Pretest & Postest & N-Gain \\
\hline Rata-rata & 15.25 & 29.36 & 0.17 \\
\hline Standar Deviasi & 6.43 & 12.10 & 0.11 \\
\hline Skor Maks & 33 & 55 & 0.43 \\
\hline Skor Min & 5 & 8 & 0.01 \\
\hline \multicolumn{4}{c}{ Uji Normalitas } \\
\hline Sig. $\alpha=0.05$ & 0.20 & 0.20 \\
\hline Keterangan & \multicolumn{4}{c}{ Berdistribusi Normal } \\
\hline \multicolumn{4}{c}{0.20} \\
\hline Sig. $\alpha=0.05$ & Uji Homogenitas \\
\hline Keterangan & 0.95 & 0.12 & 0.006 \\
\hline \multicolumn{4}{c}{ Homogen } \\
\hline Sig. $\alpha=0.05$ & Uji Mann-Whitney U & Tidak Homogen \\
\hline Keterangan & 0.26 & 0.00 \\
\hline \multicolumn{5}{c}{$\mathrm{H}_{0}$ diterima } & $\mathrm{H}_{0}$ ditolak & $\mathrm{H}_{0}$ ditolak \\
\hline
\end{tabular}

Rerata skor pretest dan posttest kemampuan berpikir kritis ditampilkan pada Gambar 1.

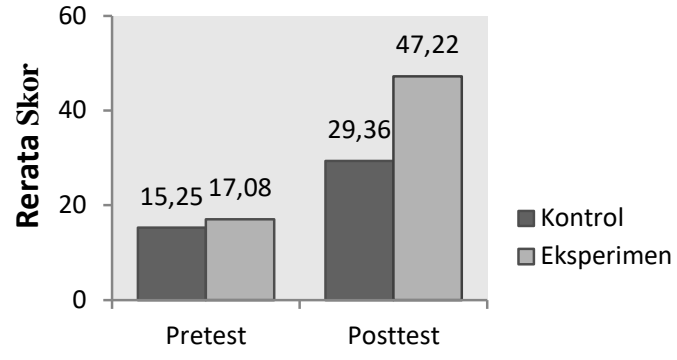

Gambar 1. Rerata Skor Pretest dan Posttest Kemampuan Berpikir Kritis Siswa

Berdasarkan Gambar 1 rerata pretest dan posttest kelas kontrol dan kelas eksperimen mengalami peningkatan, walaupun peningkatan tersebut masih jauh dari skor peningkatan ideal. Peningkatan berpikir kritis sebagai dampak penerapan PBL berbantuan TIK sehingga dapat meningkatkan motivasi belajar siswa dan juga memudahkan siswa untuk mencari sumber informasi mengenai pencemaran lingkungan yang diakibatkan oleh sampah. Menurut Pelgrum dalam Santosa (2012) penggunaan TIK mampu memotivasi siswa untuk berkolaborasi satu sama lainnya dan bertanggung jawab terhadap proses pembelajarannya. Hal tersebut juga didukung pernyataan Allan (Pardede, 2010) bahwa media pembelajaran seperti blog dan fitur-fiturnya dapat membantu mengembangkan ilmu pengetahuan dapat mengembangkan teknik berpikir kritis, logika, kemahiran berkomunikasi (lisan dan tulisan) dan mendorong pembelajar menjadi mandiri serta mampu bekerjasama. Penelitian yang telah dilakukan oleh Istiqomah dan Lutfi (2012) menyatakan bahwa pembelajaran dengan menggunakan blog ternyata dapat meningkatkan kemampuan berpikir kritis siswa. Berpikir harus dilatih secara sistematis dan terorganisir karena siswa tidak akan memiliki keterampilan berpikir kritis tanpa ditantang menggunakannya sehingga berpikir kritis harus dilatih dan tidak dapat diperoleh secara instan.

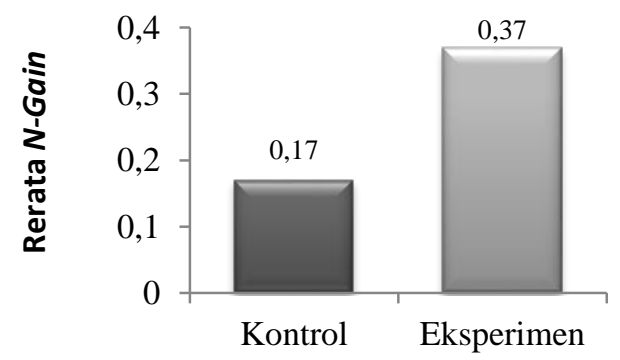

Gambar 2. Perbandingan Rerata $N$-Gain Kelas Kontrol dan Kelas Eksperimen 
Gambar 2 menunjukkan $N$-Gain kemampuan berpikir kritis di kelas eksperimen lebih tinggi dari kelas kontrol. Peningkatan berpikir kritis di kelas eksperimen yaitu 0,37 termasuk kategori sedang dan di kelas kontrol yaitu 0,17 termasuk kategori rendah. Hal tersebut terlihat pada tahap 4 penerapan PBL, siswa dituntut aktif dalam mengembangkan kemampuan berpikir kritisnya melalui kegiatan diskusi yang membahas masalah pencemaran lingkungan. Keaktifan siswa tersebut dapat disebabkan karena adanya kerjasama antar anggota kelompok sehingga dapat memancing siswa untuk mengembangkan sikap terbuka terhadap pendapat orang lain maupun dalam menyampaikan pendapat sendiri. Selain itu, adanya diskusi antar kelompok akan meningkatkan ketekunan siswa dalam kegiatan belajar, mereka akan terdorong untuk mencari jawaban dari rasa keingintahuan dan dapat memperoleh pengetahuan baru dari kelompok lain. Winkel (Roswita, 2005) menyatakan bahwa belajar kelompok akan mengabungkan beberapa pendapat yang mungkin tidak terpikirkan oleh suatu individu. Bekerja dalam kelompok diharapkan akan tercipta suasana belajar kooperatif, sehingga hasil yang diperoleh akan lebih baik daripada bila siswa belajar sendiri-sendiri. Penelitian yang telah dilakukan oleh Setiawan (2008) menunjukkan bahwa diskusi kelompok dalam PBL dapat menjadikan siswa sebagai pebelajar yang aktif karena setiap anggota kelompok mendapatkan tanggung jawab dalam kesuksesan kelompoknya. Mereka dapat saling membantu dan termotivasi untuk mengetahui dimana, apa dan bagaimana mempelajari suatu informasi. Asyari et al (2016) mengungkapkan penelitiannya dalam kegiatan lesson study bahwa implementasi PBL dapat mendorong siswa untuk berpikir kritis melalui tahapan perencanaan, diskusi, mengemukakan pertanyaan dan masalah, menganalisa dan memberikan solusi terhadap permasalahan lingkungan di sekitarnya.

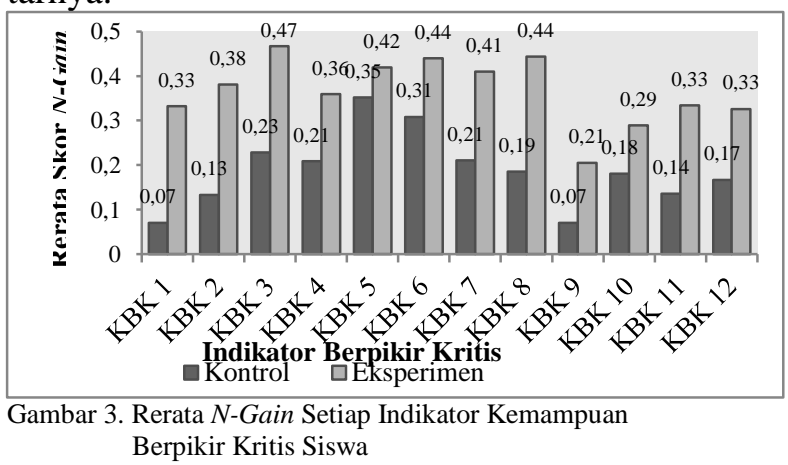

Keterangan :

KBK 1 : Memfokuskan pertanyaan; KBK 2 : Menganalisis pertanyaan; KBK 3 : Bertanya dan menjawab pertanyaan klarifikasi dan menantang; KBK 4 : Mempertimbangkan apakah sumber dapat dipercaya; KBK 5 : Mengamati dan mempertimbangkan hasil observasi; KBK 6 : Membuat deduksi dan mempertimbangkan hasil deduksi; KBK 7 : Membuat induksi dan mempertimbangkan induksi; KBK 8 : Membuat dan menentukan nilai pertimbangan yang bermanfaat; KBK 9 : Mendefinisikan istilah dan mempertimbangkan definisi; KBK 10 : Mengidentifikasi asumsi; KBK 11 : Memutuskan sebuah tindakan; dan KBK 12 : Berinteraksi dengan orang lain.

Gambar 3 menunjukkan rerata skor $N$-Gain setiap indikator kemampuan berpikir kritis siswa yang terbagi ke dalam 2 kategori yaitu kategori sedang dan kategori rendah. Pada kelas kontrol, indikator mengamati dan mempertimbangkan hasil observasi memiliki skor paling tinggi diantara kategori sedang yaitu 0,352 dan memfokuskan pertanyaan serta mendefinikan istilah masing-masing memiliki skor 0,070 yang termasuk kategori rendah. Sedangkan pada kelas eksperimen indikator bertanya dan menjawab pertanyaan memiliki yang skor paling tinggi diantara kategori sedang yaitu 0,467 dan mendefinikan istilah memiliki skor 0,205 yang termasuk kedalam kategori rendah.

Bagi sebagian siswa mengalami kesulitan untuk mendefinisikan istilah, hal itu dapat disebabkan karena beberapa siswa tidak memahami sepenuhnya istilah-istilah tersebut dan terlihat bingung pada saat pembelajaran. Kemampuan untuk mendefinisikan istilah pada setiap siswa sangat bervariasi dan hal tersebut bisa disebabkan oleh tingkat intelegensi dan motivasi belajar pada siswa itu sendiri. Hal tersebut sesuai dengan penelitian yang dilakukan oleh Suardana (2007) yang mengatakan bahwa faktor penyebab kesulitan siswa diantaranya dapat disebabkan karena siswa belajar secara hafalan sehingga mudah lupa, siswa jarang belajar di rumah kecuali ketika akan tes, masih ada siswa yang tidak terbiasa atau malu bertanya dan siswa kurang berusaha mencari sumber di berbagai media.

Hasil perhitungan $\mathrm{N}$-gain setiap indikator menunjukkan terjadi peningkatan kemampuan berpikir kritis siswa tetapi dari kedua belas indikator tersebut belum ada yang mencapai skor yang maksimal. Hal tersebut bisa disebabkan oleh beberapa faktor yang mungkin sangat berpengaruh seperti bentuk soal yang diberikan berupa pilihan ganda beralasan. Sebagian besar siswa mampu untuk menjawab option soal pilihan ganda tetapi kesulitan da- 
lam mengemukakan alasannya sehingga banyak yang tidak disertai alasannya.

Penerapan PBL berbantuan TIK dapat memberikan kesempatan kepada siswa untuk menyelidiki penyebab terjadinya pencemaran akibat sampah yang menumpuk, sehingga dari hal tersebut dapat menumbuhkan rasa ingin tahu siswa. Menurut Kubiatko dan Halakova (2009) penggunaan TIK dalam pembelajaran bukan hanya mendapatkan tingkat pengetahuan tapi juga sikap siswa terhadap materi pembelajaran dengan baik. Dahar (1996) mengungkapkan bahwa tujuan belajar adalah untuk memperoleh pengetahuan dengan suatu cara yang dapat melatih kemampuan intelektual siswa serta dapat merangsang keingintahuan siswa dan memotivasi kemampuan mereka. Siswa dapat termotivasi untuk mencari tahu sumber yang menyebabkan pencemaran, dampak yang terjadi terhadap lingkungan dan mencari tahu tindakan-tindakan untuk mengurangi terjadinya pencemaran. Siswa belajar untuk memahami materi pelajaran sehingga sehingga akan timbul kesadaran dalam diri siswa untuk mengaplikasikannya dalam kehidupan seharihari.

Parson et al (2011) mengemukakan bahwa kolaborasi antara PBL dengan 3D virtual merupakan suatu hal yang kreatif dan memberikan pengalaman belajar yang aktif serta menarik yang memungkinkan siswa untuk belajar secara efektif dalam lingkungan yang realistis. Ming Chen et al (2010) dalam penelitiannya mengatakan bahwa PBL yang di dukung oleh sumber daya digital memiliki banyak manfaat dalam tahap pembelajarannya dan meningkatkan pencarian data yang dibutuhkan dan meningkatkan kesiapan peserta didik dalam menggunakan sumber daya digital tersebut. Hal senanda diungkapkan oleh Beckmann et al (2016) dalam penelitiannya bahwa pembelajaran kolaborasi secara virtual menunjukkan proses berpikir kritis serta pengetahuan siswa dapat mengalami peningkatan.

Penggunaan TIK sangat mendukung dalam menumbuhkan rasa ingin tahu siswa dan motivasi siswa dalam belajar. Hal tersebut senada dengan penelitian yang dilakukan oleh Luthfi (2010) bahwa adanya media e-learning, $e$ book, dan web blog menjadi alternatif bagi kalangan pendidikan dalam berinteraksi dalam proses pembelajaran, dan media TIK dapat meningkatkan motivasi dan minat belajar bagi para siswa. Penggunaan blog mendapat res- pon yang baik dari siswa, walaupun pada awal penggunaannya siswa agak kesulitan ketika akan memberikan komentar karena lupa dan kurang mengerti tata cara penggunaannya, sehingga perlu dijelaskan berulang-ulang. Tetapi hal tersebut tidak mengurangi motivasi dan perhatian siswa terhadap materi pembelajaran.

Selama proses pembelajaran berlangsung, siswa bergabung dengan kelompoknya masing-masing untuk berdiskusi mengenai masalah sampah yang dapat menyebabkan pencemaran lingkungan. Bekerja sama dimaksudkan agar proses pembelajaran berlangsung optimal melalui peran aktif siswa. Dengan proses tersebut, siswa mendapatkan suatu pengetahuan baru yang dapat dikaitkan dengan pengalaman dan kehidupan pribadinya. Kegiatan diskusi yang dilakukan pada tahap tersebut dibutuhkan sikap kerjasama antar sesama anggota kelompok untuk menyelesaikan permasalahan yang disajikan. Berdasarkan teori Vygotsky dalam Arends (2007) bahwa adanya interaksi sosial dengan orang lain dapat memacu pengkonstruksian ide-ide baru dan meningkatkan perkembangan intelektual pelajar. Dengan proses tersebut, siswa mendapatkan suatu pengetahuan baru yang dapat dikaitkan dengan pengalaman dan kehidupan pribadinya. Adanya Interaksi sosial tersebut siswa dapat mengembangkan daya pikirnya dan menumbuhkan rasa kerja sama.

\section{KESIMPULAN}

Hasil penelitian dan pembahasan menunjukkan bahwa terjadi peningkatan kemampuan berpikir kritis siswa. Berdasarkan perhitungan rerata $\mathrm{N}$-Gain kelas kontrol sebesar 0,17 yang termasuk dalam kategori rendah, dan $N$-Gain kelas eksperimen sebesar 0,37 yang termasuk dalam kategori sedang. Berdasarkan hasil perhitungan $N$-gain pada kelas kontrol, indikator mengamati dan mempertimbangkan hasil observasi memiliki skor paling tinggi diantara kategori sedang dan indikator memfokuskan pertanyaan serta indikator mendefinikan istilah masing-masing memiliki skor rendah. Sedangkan pada kelas eksperimen pada setiap indikator berpikir kritis menunjukkan bahwa indikator bertanya dan menjawab pertanyaan memiliki skor paling tinggi diantara kategori sedang dan indikator mendefinisikan istilah berada pada kategori rendah. 
Berdasarkan hal tersebut, penerapan PBL berbantuan TIK dapat meningkatkan motivasi belajar siswa yang dilakukan secara berkelompok sehingga dapat meningkatkan sikap bekerja sama, karena adanya interaksi sosial antar anggota kelompok untuk mencapai kesuksesan kelompoknya dalam menyelesaikan masalah pencemaran lingkungan. Interaksi sosial tersebut sangat berpengaruh terhadap motivasi setiap siswa dalam mengikuti tahapan pembelajaran.

\section{DAFTAR PUSTAKA}

Arends, R. I. (2007). Learning to Teach. McGraw Hill. New York.

Asyari, Marhamah. Al Muhdhar, Mimien Henie Irawati. Susilo, Herawati, Ibrohim. (2016). Improving Critical Thinking Skills Through The Integration of Problem Based Learning dan Grup Investigation. International Journal for Lesson and Learning Studies, Vol. 5 Issue: 1, pp. 36-44. Emerald Group Publishing Limited. https://doi.org/10. 1108/IJLLS-10-2014-0042.

Beckmann, Jennifer. Weber, Peter. (2016). Cognitive Presence in Virtual Collaborative Learning: Assessing And Improving Critical Thinking In Online Discussion Forums. Interactive Technology and Smart Education, Vol. 13 Issue: 1, pp.52-70. Emerald Group Publishing Limited. https://doi.org/10.1108 /ITSE-12-2015-0034

Dahar, R. (1996). Teori-teori Belajar. Jakarta: Erlangga.

Fraenkel, J. R. (2006). How to Design and Evaluate Research in Education, sixth edition. McGraw-Hill Companies, Inc. New York.

Hadiryanto, S. (2009). Pembelajaran Berbasis Masalah Untuk Meningkatkan Penalaran dan Kemampuan Berpikir Kritis Siswa SMP Pada Konsep Ekosistem. Tesis pada PPs UPI. Bandung. Tidak diterbitkan.

Harsono. (2010). Peran Prior Knowledge Dalam Problem Based Learning. Pusat Pengembangan Pendidikan Universitas Gadjah Mada. Yogyakarta.

Istiqomah dan Lutfi, A. (2012). Efektivitas Penggunaan Media Blog Interaktif Untuk Meningkatkan Berpikir Kritis.
Unesa Journal of Chemical Education Vol. 1, No. 2, pp. 63-69 September 2012 ISSN: 2252-9454. [Online]. Tersedia: http://www.ejournal.unesa.ac. id. [17September 2012]

Kubiatko, M dan Halakova, Z. (2009). Slovak high school students' attitudes to ICT Using in biology lesson. Journal of Biology Education [Online]. Tersedia: www.elsevier.com/locate/comphumbeh [18 April 2011].

Luthfi, A. (2010). Pemanfaatan Teknologi Web Sebagai Media interaktif dan Pengaruhnya Terhadap Minat Belajar Bagi Mahasiswa. [Online]. Tersedia: http: /binadarma.ac.id [30 Oktober 2012].

Ming Chen-Chih. Chi Chen-Chia. (2010). Problem-Based Learning Supported By Digital Archives: Case Study of Taiwan Libraries History Digital Library. The Electronic Library, Vol. 28 Issue: 1, pp.5-28. Emerald Group Publishing Limited.https://doi.org/10.1108/026404 71011005414

Mustaji. (2010). Pengembangan Kemampuan Berpikir Kritis dan Kreatif dalam Pembelajaran. [Online]. Tersedia: http:// www.pasca.tp.ac.id [17 Desember 2012]

Pardede, P. (2010). Blog Sebagai Media Pembelajaran dan Alat Pengelolaan serta Pengembangan Ilmu di Perguruan Tinggi. [Online]. Tersedia: http://www. parlindunganpardede.wordpress.com [17 September 2012]

Parson Vanessa, Bignell Simon. (2011). Using Problem-Based Learning within 3D Virtual Worlds. in Randy Hinrichs, Charles Wankel (ed.) Transforming Virtual World Learning (Cutting-edge Technologies in Higher Education, Volume 4) Emerald Group Publishing Limited, pp. $241-261$.

Purwaningsih dan Pujianto. (2009). Pemanfaatan ICT sebagai Sumber Belajar Sains (Current Science Issue References) dalam Penerapan Problem Based Learning di Sekolah. [Online]. Tersedia: http: //www.staff.uny.ac.id [17 Des 2012]

Roswita. W. (2005). Pengaruh Pemberian Tugas secara Individual dan Kelompok Melalui Lembaran Kerja Terhadap Hasil Belajar Siswa pada Materi Lingkungan dan Pencemaran Di SMA. Tesis pada PPs UPI. Bandung. Tidak diterbitkan. 
Santosa. M. H. (2012). Pemanfaatan Blog (Jurnal Online) dalam Pembelajaran Menulis. [Online]. Tersedia: http://www .docstoc.com [17 Desember 2012]

Setiawan, I. G. (2008). Penerapan Pengajaran Kontekstual Berbasis Masalah untuk Meningkatkan Hasil Belajar Biologi Siswa Kelas $\mathrm{X}_{2}$ SMA Laboratorium Singaraja. Jurnal Penelitian dan Pengembangan Pendidikan 2 (1), 42-59. Lembaga Pendidikan Undiksha. [Online]. Tersedia: http://www.isjd.pdii. lipi.go.id [22 Oktober 2012]

Stiggins, R. J. (1994). Student-Centered Classroom Assessment. Macmillan College Publishing Company. New York.

Suardana, I. N. (2007). Kesulitan Siswa SMA Memahami Konsep Daur Biogeokimia. Jurnal Ilmiah Guru Kanderang Tingang Volume 01. No.01. Palangka Raya.

Syah, Muhibbin. (2010). Metode Pengajaran Pendidikan. [Online]. Tersedia: http:// munzaro.blogspot.com $\quad[23$ Oktober 2011] 